\title{
Pollen harvest features of the Central Amazonian bee Scaptotrigona fulvicutis Moure 1964 (Apidae: Meliponinae), in Brazil
}

\author{
Antonio Carlos Marques-Souza ${ }^{1,3}$, Maria Lúcia Absy ${ }^{1,3}$ and Warwick Estevam Kerr ${ }^{2}$
}

Received: December 20, 2005. Accepted: July 17, 2006

\begin{abstract}
RESUMO - (Aspectos da coleta de pólen de Scaptotrigona fulvicutis 1964 (Apidae: Meliponinae), abelha da Amazônia Central, Brasil). Durante o período de doze meses, o pólen transportado por Scaptotrigona fulvicutis Moure 1964 foi coletado das corbículas das operárias, logo após o fechamento da entrada das colméias. Feita a identificação polínica dos grãos, sua freqüência mensal nas amostras e o agrupamento por famílias botânicas, constatou-se que as mais visitadas foram: Mimosaceae, Myrtaceae e Sapindaceae. As operárias coletaram o pólen de 97 espécies de plantas distribuídas em 73 gêneros e 36 famílias, sendo as mais freqüentes: Stryphnodendron guianense (Aubl.) Benth. em abril (57,37\%) e Schefflera morototoni (Aubl.) Frodin em maio (54,73\%). A matriz de abundância dos tipos polínicos coletados mostrou que a dissimilaridade de espécies entre os meses foi pequena o que resultou na formação de dois grandes grupos.
\end{abstract}

Palavras-chave: Pólen, abelhas sem ferrão, Apidae, Meliponinae, Scaptotrigona fulvicutis, Amazônia

\begin{abstract}
Pollen harvest features of the Central Amazonian bee Scaptotrigona fulvicutis Moure 1964 (Apidae: Meliponinae), in Brazil). Over a twelve-month period, pollen loads transported by Scaptotrigona fulvicutis Moure 1964 were collected from the workers corbiculae right after the hive entrance closure in an area of old secondary forest mixed with some exotic fruit trees and ornamentals. Once the pollen grains were identified, their monthly frequency in the samples and grouping by botanical family established that Mimosaceae, Myrtaceae and Sapindaceae were the most frequently visited. The workers harvested the pollen from 97 plant species distributed in 73 genera and 36 families, mostly: Stryphnodendron guianense (Aubl.) Benth. in April (57,37\%) and Schefflera morototoni (Aubl.) Frodin in May $(54,73 \%)$. The harvested pollen types abundance matrix showed that there was little species dissimilarity between the months, which resulted in the formation of two large groups.
\end{abstract}

Key words: Pollen, stingless bee, Apidae, Meliponinae, Scaptotrigona fulvicutis, Amazônia

\section{Introduction}

Social bees represent a very important group of pollinators harvesting nectar and pollen in the tropical regions (Lobreau-Callen et al. 1990). They are responsible for higher production of fruits and seeds (Nassar \& Carvalho 1990) through migratory apiculture in several parts of Brazil. The Meliponinae stand out in this process since they are able to adapt themselves to competition from exotic bees, such as Apis mellifera L.

Stingless bees play an essential role in the fertilization of plant species, and are the main pollinators of many plants in the Amazon region. The majority of these plants are bisexual, requiring an external agent for carrying pollen from one flower to another. According to Johnson \& Hubbell (1974), Meliponinae make up the greatest share of insect biomass feeding on pollen and nectar. The massive presence of these insects in the flowers makes up such an ecological complex and such an interaction, that without plants, bees would disappear within two months. Likewise, without bees, the many flowering plant species would disappear within one or two generations (Kerr 1978).

Meliponinae are well adapted to cope with all the biotic and abiotic factors imposed on them by the Amazon region. Nonetheless, as it is from the forest that they get their food, habitat loss brought about by clearing and/or burning the vegetation, might destabilize the plant-visitor ratio and reduce native stingless bee populations.

Therefore, determining the Meliponinae ecological niches, niche overlap, strategies and constancy of pollen harvests, will provide a better understanding of

\footnotetext{
1 Instituto Nacional de Pesquisas da Amazônia, CPBO, C. Postal 478, 69011-970 Manaus, AM, Brazil (luciabsy@inpa.gov.br)

2 Universidade Federal de Uberlândia, Departamento de Genética e Bioquímica, Bloco 2, sala 20, 38400-902 Uberlândia, MG, Brazil

3 Corresponding author: msouza@inpa.gov.br
} 
the biology of these bees. Similarly, surveys of the plants used as pollen and nectar sources will reveal the Meliponid's food preferences; these plant species can be used in afforestation schemes, which will benefit bee populations.

\section{Material and methods}

The nests were introduced in old regrowth forest on the campus of INPA-Instituto Nacional de Pesquisas da Amazônia, in Manaus, Brazil, $3^{\circ} 08^{\prime} \mathrm{S}$ and $60^{\circ} 10^{\prime} \mathrm{W}$ at an altitude of 40 meters a.s.1.

We obtained pollen samples from five bees from a nest of Scaptotrigona fulvicutis Moure 1964 on alternate days, between 07:00 and 09:00 h from August 1995 to July 1996. The entrance of the hive was closed and the bees arriving with pollen loads were captured, their loads removed with the tip of a stiletto and stored in sterilised glass vials. Bees were set free after removing the pollen loads from their corbiculae.

Ten $\mathrm{ml}$ of acetic acid was added to each pollen sample, then left to rest for $24 \mathrm{~h}$. Following this period, the samples were acetolysed using Erdtman's method (1960). After preparation, the pollen is mount in glycerin jelly on a slide and sealed with paraffin. We counted and identified about 1,000 pollen grains from each sample and expressed the results of that count in percentages.

The term "attractive" was used to indicate the pollen frequency from each plant species harvested by Scaptotrigona fulvicutis Moure 1964, the more frequent the more attractive.

Cormack (1971) and Everitt (1974) proposed the grouping methodology for statistical analysis. Euclidean Distance (ED) was the metric used for indicating the proximity between samples $\mathrm{A}$ and $\mathrm{B}$, where each axis in feature space is the percent of each pollen type in the sample according to the formula below:

$$
d(A, B)=\left[\sum_{i=1}^{p}\left(\left(x_{i}(A)-x_{i}(B)\right)^{2}\right]^{1 / 2}\right.
$$

Or in matrix notation:

$$
d(A, B)=\left[\sum_{i=1}^{p}\left(\left(x_{i}(A)-x_{i}(B)\right)^{2}\right]^{1 / 2}\right.
$$

\section{Results}

Over the entire study period from August 1995 to July 1996, Scaptotrigona fulvicutis Moure 1964 collected pollen from 97 different plant species belonging to 73 genera and 36 families. The number of plant species varied from 37 in January to 11 in June (Table 1). Of that total the abundance and frequency of six plant species, Stryphnodendron guianense (Aubl.) Benth., Matayba sp. 1., Myrcia amazonica DC., Tapirira guianensis Aubl., Inga Mill. and Croton matourensis Aubl. were responsible for the most significant part of the harvests performed by Scaptotrigona fulvicutis Moure 1964. These species contributed over $50 \%$ of all the pollen collected throughout the year (Table 2).

The matrix of Euclian distances based on mean monthly percentage abundance of harvested pollen types showed that there was little species dissimilarity between the months $(E D=3,345 \pm 1,404)$. This resulted in the formation of two large groups: 1) August, September, October, November, December and January; 2) February, March, June, July, April and May (Fig. 1). The main species contributing to similarity within the first group are: Tapirira guianensis Aubl., Thyrsodium sp., Tabebuia serratifolia (Vahl) G. Nicholson, Aparisthmium cordatum (Juss.) Baill., Croton matourensis Aubl., Miconia myriantha Benth., Stryphnodendron guianense (Aubl.) Benth., Myrcia amazonica DC., Matayba sp. 1 and 2, Sapotaceae type, among others. The main species of the second group are: Schefflera morototoni (Aubl.) Frodin, Physocalymma scaberrimum Pohl, Inga sp., Parkia sp., Vitex sp., Croton matourensis Aubl., Matayba sp. 1 and Stryphnodendron guianense (Aubl.) Benth.

Some pollen sources exerted a great influence on the collections performed by Scaptotrigona fulvicutis Moure 1964 and presented a high degree of attractiveness over consecutive months. This was the

Table 1. Monthly distribution of the pollen harvest by Scaptotrigona fulvicutis Moure 1964.

\begin{tabular}{llccc}
\hline Year & Month & $\begin{array}{c}\text { N. of species } \\
\text { harvested }\end{array}$ & $\begin{array}{c}\text { Dist. by } \\
\text { genera }\end{array}$ & $\begin{array}{c}\text { Dist. by } \\
\text { families }\end{array}$ \\
\hline 1995 & August & 18 & 18 & 13 \\
& September & 19 & 19 & 13 \\
& October & 28 & 25 & 18 \\
& November & 25 & 17 & 12 \\
& December & 17 & 12 & 12 \\
& January & 37 & 33 & 22 \\
& February & 21 & 19 & 17 \\
& March & 21 & 19 & 15 \\
& April & 14 & 14 & 12 \\
& May & 15 & 14 & 12 \\
& June & 11 & 11 & 8 \\
& July & 16 & 16 & 13 \\
\hline
\end{tabular}


Table 2. List of the pollen types harvested by Scaptotrigona fulvicutis Moure 1964 from August 1995 to July 1996 and their attractiveness (expressed in \%).

\begin{tabular}{|c|c|c|c|c|c|c|c|c|c|c|c|c|}
\hline Family/Species & Aug & Sep & Oct & Nov & Dec & Jan & Feb & Mar & Apr & May & Jun & Jul \\
\hline \multicolumn{13}{|l|}{ ACANTHACEAE } \\
\hline Acanthaceae tipo & 0.00 & 0.00 & 0.00 & 0.00 & 0.02 & 0.00 & 0.00 & 0.00 & 0.00 & 0.00 & 0.00 & 0.00 \\
\hline \multicolumn{13}{|l|}{ AMARANTHACEAE } \\
\hline Alternanthera sp. & 0.00 & 0.03 & 0.03 & 0.01 & 0.00 & 0.07 & 0.00 & 0.00 & 0.00 & 0.00 & 0.00 & 0.01 \\
\hline \multicolumn{13}{|l|}{ ANACARDIACEAE } \\
\hline Spondias mombin L. & 1.28 & 0.14 & 0.05 & 0.00 & 0.01 & 0.04 & 0.00 & 0.00 & 0.00 & 0.00 & 0.00 & 0.00 \\
\hline Tapirira guianensis Aubl. & 15.12 & 14.74 & 28.70 & 13.10 & 0.00 & 0.64 & 0.27 & 0.01 & 0.00 & 0.00 & 0.00 & 0.00 \\
\hline Thyrsodium sp. & 0.00 & 31.06 & 0.00 & 2.55 & 0.00 & 0.05 & 0.00 & 0.00 & 0.00 & 0.00 & 0.00 & 0.00 \\
\hline \multicolumn{13}{|l|}{ APOCYNACEAE } \\
\hline Aspidosperma sp. & 0.00 & 0.00 & 0.01 & 0.00 & 0.00 & 0.00 & 0.00 & 0.00 & 0.00 & 0.00 & 0.00 & 0.00 \\
\hline \multicolumn{13}{|l|}{ AQUIFOLIACEAE } \\
\hline Ilex sp. & 0.00 & 0.00 & 0.00 & 0.00 & 0.00 & 0.02 & 0.00 & 0.00 & 0.00 & 0.00 & 0.00 & 0.00 \\
\hline \multicolumn{13}{|l|}{ ARALIACEAE } \\
\hline \multicolumn{12}{|l|}{ Frodin } & 0.01 \\
\hline \multicolumn{13}{|l|}{ ARECACEAE } \\
\hline Arecaceae tipo & 0.00 & 0.00 & 0.00 & 0.00 & 0.00 & 0.00 & 0.00 & 0.00 & 0.00 & 0.00 & 0.02 & 0.00 \\
\hline Bactris gasipaes H.B.K. & 0.00 & 0.00 & 0.01 & 0.00 & 0.00 & 0.00 & 0.00 & 0.00 & 0.00 & 0.00 & 0.00 & 0.00 \\
\hline Cocos sp. & 0.00 & 0.00 & 0.01 & 0.00 & 0.00 & 0.00 & 0.00 & 0.00 & 0.00 & 0.00 & 0.00 & 0.00 \\
\hline Euterpe precatoria Mart. & 0.00 & 0.00 & 0.00 & 0.00 & 0.00 & 0.00 & 0.00 & 0.00 & 0.00 & 0.00 & 0.00 & 0.01 \\
\hline Euterpe sp. & 0.02 & 0.00 & 0.00 & 0.00 & 0.00 & 0.07 & 0.04 & 0.01 & 0.00 & 0.00 & 0.00 & 0.00 \\
\hline Mauritia flexuosa L. f. & 0.02 & 0.00 & 0.00 & 0.00 & 0.00 & 0.04 & 0.00 & 0.00 & 0.00 & 0.00 & 0.00 & 0.00 \\
\hline Maximiliana maripa (Aubl.) Drude & 0.00 & 0.00 & 0.00 & 0.00 & 0.00 & 0.00 & 0.06 & 0.00 & 0.00 & 0.00 & 0.00 & 0.00 \\
\hline Oenocarpus sp. & 0.00 & 0.00 & 0.00 & 0.00 & 0.00 & 0.01 & 0.01 & 0.00 & 0.00 & 0.00 & 0.00 & 0.00 \\
\hline \multicolumn{13}{|l|}{ ASTERACEAE } \\
\hline Ambrosia sp. & 0.00 & 0.00 & 0.00 & 0.00 & 0.00 & 0.00 & 0.01 & 0.00 & 0.00 & 0.00 & 0.00 & 0.00 \\
\hline Aster sp. & 0.00 & 0.00 & 0.00 & 0.00 & 0.00 & 0.01 & 0.00 & 0.00 & 0.00 & 0.01 & 0.00 & 0.00 \\
\hline Asteraceae tipo & 0.00 & 0.00 & 0.00 & 0.00 & 0.01 & 0.00 & 0.00 & 0.00 & 0.00 & 0.00 & 0.00 & 0.00 \\
\hline Mikania sp. & 0.00 & 0.00 & 0.00 & 0.00 & 0.00 & 0.00 & 0.00 & 0.00 & 0.00 & 0.00 & 0.00 & 8.18 \\
\hline \multicolumn{13}{|l|}{ BIGNONIACEAE } \\
\hline $\begin{array}{l}\text { Tabebuia serratifolia (Vahl) } \\
\text { G. Nicholson }\end{array}$ & 18.81 & 9.68 & 0.00 & 0.00 & 0.00 & 0.00 & 0.00 & 0.00 & 0.00 & 0.00 & 0.00 & 3.14 \\
\hline \multicolumn{13}{|l|}{ BIXACEAE } \\
\hline Bixa orellana L. & 0.00 & 0.00 & 0.00 & 0.00 & 0.00 & 0.00 & 0.01 & 0.00 & 0.02 & 0.00 & 0.00 & 0.00 \\
\hline \multicolumn{13}{|l|}{ BURSERACEAE } \\
\hline Protium sp. & 0.00 & 0.00 & 0.01 & 0.00 & 0.00 & 0.00 & 0.00 & 0.00 & 0.05 & 0.00 & 0.00 & 0.00 \\
\hline \multicolumn{13}{|l|}{ CAESALPINIACEAE } \\
\hline Bauhinia rutilans Spruce ex Benth. & 0.00 & 0.00 & 0.00 & 0.00 & 0.00 & 0.01 & 0.00 & 0.00 & 0.00 & 0.00 & 0.00 & 0.00 \\
\hline Cassia latifolia G. Mey. & 0.00 & 0.00 & 0.00 & 0.00 & 0.00 & 0.00 & 0.06 & 0.00 & 0.00 & 0.00 & 0.00 & 0.00 \\
\hline $\begin{array}{l}\text { Schizolobium amazonicum Huber } \\
\text { \& Ducke }\end{array}$ & 0.00 & 0.00 & 8.39 & 0.00 & 0.00 & 0.00 & 0.00 & 0.00 & 0.00 & 0.00 & 0.00 & 0.00 \\
\hline \multicolumn{13}{|l|}{ CARICACEAE } \\
\hline Carica papaya $\mathrm{L}$. & 0.00 & 0.00 & 8.40 & 0.00 & 0.00 & 0.00 & 0.00 & 0.00 & 0.00 & 0.00 & 0.00 & 0.00 \\
\hline \multicolumn{13}{|l|}{ CECROPIACEAE } \\
\hline Cecropia sp. & 0.02 & 0.02 & 0.26 & 0.08 & 0.08 & 0.34 & 0.10 & 0.31 & 0.02 & 0.08 & 0.00 & 0.04 \\
\hline \multicolumn{13}{|l|}{ CLUSIACEAE } \\
\hline Vismia $\mathrm{sp}$ & 0.00 & 0.00 & 0.00 & 0.00 & 0.00 & 0.00 & 0.00 & 0.00 & 10.09 & 0.00 & 0.00 & 0.00 \\
\hline \multicolumn{13}{|l|}{ EUPHORBIACEAE } \\
\hline Alchornea sp. & 0.00 & 0.00 & 0.00 & 0.00 & 0.00 & 0.08 & 0.00 & 0.00 & 0.00 & 0.00 & 0.00 & 0.00 \\
\hline $\begin{array}{l}\text { Aparisthmium cordatum (Juss.) } \\
\text { Baill. }\end{array}$ & 0.00 & 0.00 & 0.00 & 20.07 & 0.97 & 0.01 & 0.00 & 0.01 & 1.00 & 0.00 & 0.08 & 0.00 \\
\hline Croton matourensis Aubl. & 0.00 & 0.05 & 0.00 & 0.00 & 0.00 & 44.00 & 43.54 & 15.27 & 0.00 & 0.01 & 0.00 & 0.00 \\
\hline Euphorbia sp. & 0.00 & 0.00 & 0.00 & 7.13 & 0.00 & 0.00 & 0.00 & 0.00 & 0.00 & 0.00 & 0.00 & 0.00 \\
\hline Euphorbiaceae tipo & 0.00 & 0.00 & 0.00 & 0.23 & 0.00 & 0.00 & 0.00 & 0.00 & 0.00 & 0.00 & 0.00 & 0.00 \\
\hline Mabea sp. & 0.00 & 0.00 & 0.00 & 1.17 & 0.00 & 0.05 & 0.00 & 0.00 & 0.00 & 0.00 & 0.00 & 0.00 \\
\hline
\end{tabular}


Table 2 (continuation)

\begin{tabular}{|c|c|c|c|c|c|c|c|c|c|c|c|c|}
\hline Family/Species & Aug & Sep & Oct & Nov & Dec & Jan & Feb & Mar & Apr & May & Jun & Jul \\
\hline \multicolumn{13}{|l|}{ FABACEAE } \\
\hline Andira sp. & 0.00 & 0.00 & 0.00 & 0.00 & 0.00 & 0.00 & 0.00 & 11.16 & 0.00 & 0.00 & 0.00 & 0.00 \\
\hline Derris sp. & 0.00 & 0.00 & 0.00 & 0.00 & 0.00 & 0.00 & 0.00 & 0.00 & 0.00 & 2.09 & 0.00 & 0.00 \\
\hline Dipterix sp. & 0.00 & 0.00 & 0.00 & 0.00 & 0.00 & 0.00 & 0.02 & 0.00 & 0.00 & 0.00 & 0.00 & 0.00 \\
\hline Machaerium sp. & 0.00 & 0.00 & 0.00 & 0.00 & 2.37 & 0.04 & 0.00 & 0.00 & 0.00 & 0.00 & 0.00 & 0.00 \\
\hline Vataireopsis sp. & 0.00 & 0.00 & 0.00 & 0.00 & 0.00 & 0.00 & 0.00 & 0.00 & 0.00 & 0.00 & 0.00 & 0.16 \\
\hline \multicolumn{13}{|l|}{ LAMIACEAE } \\
\hline Cuphea sp. & 0.00 & 0.00 & 0.00 & 0.00 & 0.00 & 0.01 & 0.00 & 0.00 & 0.00 & 0.00 & 0.00 & 0.00 \\
\hline Hyptis sp. & 0.00 & 0.00 & 0.00 & 0.00 & 0.00 & 0.04 & 0.00 & 0.00 & 0.00 & 0.00 & 0.00 & 0.00 \\
\hline \multicolumn{13}{|l|}{ LECYTHIDACEAE } \\
\hline Corythophora sp. & 0.00 & 0.00 & 0.00 & 0.00 & 0.00 & 0.00 & 0.00 & 0.00 & 0.04 & 0.00 & 0.00 & 0.00 \\
\hline \multicolumn{13}{|l|}{ LORANTHACEAE } \\
\hline Loranthaceae tipo & 0.00 & 0.00 & 0.00 & 0.00 & 0.00 & 0.00 & 1.73 & 0.00 & 0.00 & 0.00 & 0.00 & 0.00 \\
\hline \multicolumn{13}{|l|}{ LYTHRACEAE } \\
\hline Physocalymma scaberrimum Pohl & 9.82 & 0.00 & 0.00 & 0.00 & 0.00 & 0.00 & 15.24 & 2.08 & 0.00 & 0.71 & 24.47 & 0.00 \\
\hline \multicolumn{13}{|l|}{ MALPIGHIACEAE } \\
\hline Byrsonima sp. & 0.26 & 0.03 & 0.04 & 0.00 & 7.44 & 0.01 & 0.00 & 0.06 & 0.00 & 0.00 & 0.00 & 0.00 \\
\hline \multicolumn{13}{|c|}{ MELASTOMATACEAE } \\
\hline Bellucia grossularioides (L.) Triana & 0.01 & 0.01 & 0.00 & 0.02 & 0.00 & 0.00 & 0.00 & 0.00 & 0.00 & 0.00 & 0.00 & 0.00 \\
\hline Miconia myriantha Benth. & 0.07 & 0.00 & 0.00 & 26.72 & 0.00 & 0.00 & 0.00 & 0.07 & 0.04 & 0.02 & 0.00 & 0.00 \\
\hline Miconia sp. & 0.00 & 0.16 & 0.18 & 0.00 & 0.00 & 0.16 & 0.00 & 0.00 & 0.00 & 0.00 & 0.00 & 0.02 \\
\hline \multicolumn{13}{|l|}{ MELIACEAE } \\
\hline Melia sp. & 0.02 & 0.00 & 0.00 & 0.00 & 0.00 & 0.00 & 0.00 & 0.00 & 0.00 & 0.00 & 0.00 & 0.00 \\
\hline Meliaceae type 1 & 0.00 & 0.00 & 4.97 & 0.34 & 0.00 & 0.00 & 0.00 & 0.00 & 0.00 & 0.00 & 0.00 & 0.00 \\
\hline Meliaceae type 2 & 0.00 & 0.00 & 0.00 & 0.00 & 0.10 & 0.00 & 0.00 & 0.00 & 0.00 & 0.00 & 0.00 & 0.00 \\
\hline Swietenia macrophylla King & 0.00 & 0.00 & 0.00 & 0.00 & 0.00 & 0.00 & 0.01 & 0.00 & 0.00 & 0.00 & 0.00 & 0.00 \\
\hline \multicolumn{13}{|l|}{ MIMOSACEAE } \\
\hline Inga sp. & 0.00 & 0.00 & 11.61 & 0.00 & 0.00 & 0.00 & 0.00 & 20.43 & 0.00 & 6.60 & 0.84 & 19.48 \\
\hline Enterolobium schomburgkii Benth. & 0.00 & 0.65 & 0.00 & 0.00 & 0.00 & 0.00 & 0.00 & 0.00 & 0.00 & 0.00 & 0.00 & 0.00 \\
\hline Leucaena $\mathrm{sp}$. & 0.00 & 0.00 & 0.00 & 0.00 & 0.00 & 0.00 & 0.00 & 0.04 & 0.00 & 0.00 & 0.00 & 0.00 \\
\hline Mimosa invisa Mart. ex Colla & 0.00 & 0.00 & 0.00 & 0.00 & 0.00 & 0.01 & 0.49 & 0.02 & 0.00 & 0.00 & 0.00 & 0.00 \\
\hline $\begin{array}{l}\text { Mimosa microcephala Humb. } \\
\text { G. Bonpl. }\end{array}$ & 0.00 & 0.00 & 0.00 & 0.00 & 1.40 & 0.00 & 0.00 & 0.00 & 0.00 & 0.52 & 0.00 & 0.00 \\
\hline Mimosa pudica L. & 0.01 & 0.00 & 0.02 & 0.02 & 0.12 & 2.52 & 0.72 & 0.41 & 0.07 & 0.02 & 0.00 & 0.01 \\
\hline Mimosa $\mathrm{sp}$ & 0.00 & 0.00 & 0.00 & 0.37 & 0.00 & 0.00 & 0.00 & 0.00 & 0.00 & 0.00 & 0.00 & 0.00 \\
\hline Parkia sp. & 0.00 & 0.00 & 0.00 & 0.00 & 0.00 & 0.00 & 0.00 & 0.00 & 0.00 & 0.00 & 40.65 & 0.20 \\
\hline Piptadeniasp. & 0.00 & 0.00 & 0.00 & 0.00 & 0.00 & 0.00 & 0.00 & 0.25 & 0.01 & 0.00 & 0.00 & 0.00 \\
\hline Pithecellobium sp. & 0.00 & 1.93 & 0.00 & 0.00 & 0.00 & 0.00 & 0.00 & 0.00 & 0.00 & 0.00 & 0.00 & 0.00 \\
\hline Stryphnodendron guianense Benth. & 33.93 & 10.13 & 13.84 & 0.02 & 0.00 & 0.08 & 37.17 & 12.49 & 57.37 & 28.11 & 14.17 & 12.30 \\
\hline $\begin{array}{l}\text { Stryphnodendron pulcherrimum } \\
\text { (Willd.) Hochr. }\end{array}$ & 0.00 & 0.00 & 0.00 & 0.10 & 0.00 & 0.00 & 0.00 & 0.00 & 0.00 & 0.00 & 0.00 & 0.00 \\
\hline \multicolumn{13}{|l|}{ MYRTACEAE } \\
\hline Eugenia sp. & 0.00 & 0.00 & 0.00 & 6.19 & 4.75 & 0.00 & 0.00 & 0.00 & 0.00 & 3.51 & 1.97 & 0.00 \\
\hline Myrcia amazonica DC. & 8.19 & 10.48 & 0.18 & 8.05 & 17.79 & 26.29 & 0.42 & 0.14 & 0.00 & 0.00 & 0.00 & 0.00 \\
\hline Myrtaceae tipo & 0.00 & 0.00 & 0.00 & 0.00 & 10.45 & 0.00 & 0.00 & 0.00 & 0.00 & 0.00 & 0.00 & 0.00 \\
\hline Psidium sp. & 0.00 & 0.00 & 0.00 & 0.00 & 0.00 & 0.00 & 0.00 & 0.00 & 0.00 & 0.00 & 6.98 & 0.04 \\
\hline Syzygium jambolanum DC. & 0.00 & 0.00 & 0.06 & 0.00 & 0.00 & 0.00 & 0.00 & 0.00 & 0.00 & 0.00 & 0.00 & 0.00 \\
\hline \multicolumn{13}{|l|}{ OXALIDACEAE } \\
\hline Averrhoa carambola L. & 0.00 & 0.00 & 0.00 & 0.00 & 7.15 & 0.01 & 0.00 & 0.00 & 0.00 & 0.00 & 0.00 & 10.92 \\
\hline \multicolumn{13}{|l|}{ PIPERACEAE } \\
\hline Piper sp. & 0.00 & 0.00 & 0.00 & 0.00 & 0.00 & 0.02 & 0.00 & 0.00 & 0.00 & 0.00 & 0.00 & 0.00 \\
\hline Piperomia sp. & 0.00 & 0.00 & 0.00 & 0.00 & 0.03 & 0.07 & 0.00 & 0.00 & 0.00 & 0.00 & 0.00 & 0.00 \\
\hline \multicolumn{13}{|l|}{ POACEAE } \\
\hline Poaceae type & 0.00 & 0.00 & 0.00 & 0.00 & 0.00 & 0.04 & 0.00 & 0.01 & 0.00 & 0.00 & 0.00 & 0.00 \\
\hline \multicolumn{13}{|l|}{ RUBIACEAE } \\
\hline Borreria sp. & 0.00 & 0.00 & 0.00 & 0.00 & 0.00 & 0.19 & 0.00 & 0.01 & 0.00 & 0.00 & 0.00 & 0.00 \\
\hline Genipa americana L. & 0.00 & 0.00 & 0.21 & 0.01 & 0.00 & 0.00 & 0.00 & 0.00 & 0.00 & 0.00 & 0.00 & 0.00 \\
\hline
\end{tabular}


Table 2 (continuation)

\begin{tabular}{|c|c|c|c|c|c|c|c|c|c|c|c|c|}
\hline Family/Species & Aug & Sep & Oct & Nov & Dec & Jan & Feb & Mar & Apr & May & Jun & Jul \\
\hline Rubiaceae type 2 & 0.00 & 0.00 & 0.00 & 0.00 & 0.00 & 0.00 & 0.00 & 0.00 & 0.00 & 0.00 & 0.00 & 23.35 \\
\hline $\begin{array}{l}\text { Warszewiczia coccinea (Vahl.) } \\
\text { Klotzsch }\end{array}$ & 0.00 & 0.00 & 2.53 & 0.00 & 0.00 & 0.04 & 0.00 & 0.00 & 0.00 & 0.00 & 0.00 & 0.00 \\
\hline \multicolumn{13}{|l|}{ SAPINDACEAE } \\
\hline Cupania hispida Radlk. & 10.19 & 0.00 & 0.00 & 0.00 & 0.00 & 0.00 & 0.00 & 0.00 & 0.00 & 0.00 & 0.00 & 0.00 \\
\hline Matayba sp. 1 & 2.18 & 20.05 & 0.93 & 11.31 & 17.97 & 2.75 & 0.01 & 37.10 & 0.64 & 0.00 & 10.77 & 22.12 \\
\hline Matayba sp. 2 & 0.00 & 0.00 & 0.00 & 0.00 & 0.00 & 11.72 & 0.00 & 0.00 & 0.00 & 0.00 & 0.00 & 0.00 \\
\hline Sapindaceae type & 0.00 & 0.00 & 0.00 & 1.35 & 29.37 & 10.26 & 0.00 & 0.00 & 0.00 & 0.00 & 0.00 & 0.00 \\
\hline Serjania sp. & 0.00 & 0.18 & 0.00 & 0.00 & 0.00 & 0.00 & 0.00 & 0.00 & 0.00 & 0.01 & 0.00 & 0.00 \\
\hline Talisia sp. & 0.00 & 0.00 & 0.05 & 0.00 & 0.00 & 0.01 & 0.00 & 0.00 & 0.00 & 0.00 & 0.00 & 0.00 \\
\hline \multicolumn{13}{|l|}{ SAPOTACEAE } \\
\hline Manilkara sp. & 0.02 & 0.00 & 0.00 & 0.00 & 0.00 & 0.00 & 0.00 & 0.00 & 0.00 & 0.00 & 0.00 & 0.00 \\
\hline Pouteria sp. 1 & 0.00 & 0.01 & 0.02 & 0.04 & 0.00 & 0.00 & 0.00 & 0.10 & 0.01 & 0.00 & 0.00 & 0.00 \\
\hline Pouteria sp. 2 & 0.00 & 0.00 & 0.00 & 0.92 & 0.00 & 0.00 & 0.00 & 0.00 & 0.00 & 0.00 & 0.00 & 0.00 \\
\hline Sapotaceae type 1 & 0.00 & 0.00 & 0.00 & 0.14 & 0.00 & 0.00 & 0.00 & 0.00 & 0.00 & 0.00 & 0.00 & 0.00 \\
\hline Sapotaceae type 2 & 0.00 & 0.00 & 0.00 & 0.00 & 0.00 & 0.01 & 0.00 & 0.00 & 0.00 & 0.00 & 0.00 & 0.00 \\
\hline \multicolumn{13}{|l|}{ SCROPHULARIACEAE } \\
\hline Conobea sp. & 0.00 & 0.00 & 0.00 & 0.00 & 0.00 & 0.00 & 0.00 & 0.00 & 0.00 & 0.74 & 0.00 & 0.00 \\
\hline SOLANACEAE & & & & & & & & & & & & \\
\hline Solanum sp. & 0.00 & 0.00 & 0.00 & 0.00 & 0.00 & 0.00 & 0.04 & 0.00 & 0.00 & 0.00 & 0.00 & 0.00 \\
\hline \multicolumn{13}{|l|}{ VERBENACEAE } \\
\hline $\begin{array}{l}\text { Lantana camara } \mathrm{L} . \\
\text { VERBENACEAE }\end{array}$ & 0.00 & 0.00 & 7.58 & 0.00 & 0.00 & 0.00 & 0.00 & 0.00 & 0.00 & 0.00 & 0.00 & 0.00 \\
\hline Vitex sp. & 0.00 & 0.05 & 0.13 & 0.00 & 0.00 & 0.01 & 0.00 & 0.00 & 26.39 & 2.85 & 0.02 & 0.00 \\
\hline \multicolumn{13}{|l|}{ VITACEAE } \\
\hline Cissus sp. & 0.00 & 0.00 & 0.06 & 0.00 & 0.00 & 0.00 & 0.03 & 0.01 & 0.00 & 0.00 & 0.00 & 0.00 \\
\hline \multicolumn{13}{|l|}{ UNDETERMINED } \\
\hline Type Meliaceae & 0.00 & 0.00 & 0.00 & 0.02 & 0.00 & 0.00 & 0.00 & 0.00 & 0.00 & 0.00 & 0.00 & 0.00 \\
\hline Type Portulacaceae & 0.00 & 0.00 & 9.72 & 0.00 & 0.00 & 0.00 & 0.00 & 0.00 & 0.00 & 0.00 & 0.00 & 0.00 \\
\hline Type Verbenaceae & 0.00 & 0.00 & 1.99 & 0.00 & 0.00 & 0.00 & 0.00 & 0.00 & 0.00 & 0.00 & 0.00 & 0.00 \\
\hline Total (\%) & 100.00 & 100.00 & 100.00 & 100.00 & 100.00 & 100.00 & 100.00 & 100.00 & 100.00 & 100.00 & 100.00 & 100.00 \\
\hline
\end{tabular}

case of Stryphnodendron guianense (Aubl.) Benth., which had its pollen collected during eleven months and attained a peak attractiveness of $57,37 \%$ in April. The pollen from this plant was not attractive to this bee only in the months of November, January and December (when there was no collection). In all other months, the attractiveness of this one species exceeded $10,0 \%$. Another plant whose pollen was frequent in the collections of this bee species was Matayba sp., which also appeared in eleven months, being attractive in March with $37,10 \%$, in July with $22,12 \%$ and in September with $20,05 \%$. In spite of being frequent in five months, the species Croton matourensis Aubl. was well collected in only three, presenting its greatest attractiveness in January when it reached $44,0 \%$. In the following month, the attractiveness of that plant remained high with $43,54 \%$ while in March it dropped to $15,27 \%$. There were other plants with great attractiveness but low frequency of months. Tapirira guianensis Aubl. was frequent in seven months of the collections by Scaptotrigona fulvicutis Moure 1964 (Fig. 2). It showed significant attractiveness in October with 28,70\%. Schefflera morototoni (Aubl.) Frodin was present in nine months, but was attractive in May with 54,73\%. Myrcia amazonica DC. was frequent in eight collecting months and significantly attractive in January with $26,29 \%$ and in four other months. Aparisthmium cordatum (Juss.) Baill. was present in six months with attractiveness of $20,07 \%$ in November. Miconia myriantha Benth. was frequent in five months, but also attractive in November with $26,72 \%$. Inga sp. was frequent in five months and attractive in two: March with 20,43\% and July with 19,48\%. Physocalymma scaberrimum Pohl was frequent in five months but with significant attractiveness only in June with 24,47\% and February with 15,24\%. Parkia $\mathrm{sp}$. was frequent in two months with high attractiveness rate only in June with $40,65 \%$. Moreover, Vitex sp., having pollen present in five months, was attractive to Scaptotrigona fulvicutis Moure 1964 only in April 


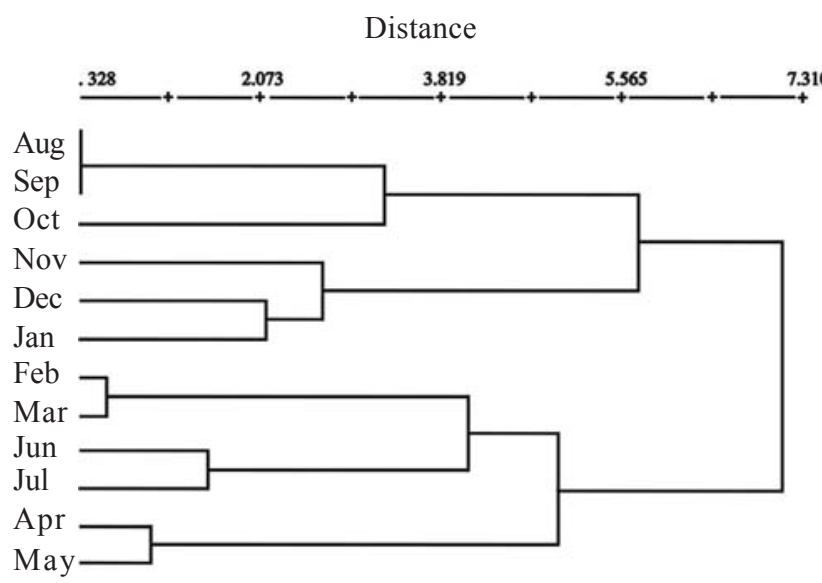

Figure 1. Abundance similarity dendrogram of species harvested for pollen by Scaptotrigona fulvicutis Moure 1964, using Wards methods and Euclidean distance. with $26,39 \%$. In spite of having had, an attractiveness of $23,35 \%$ in July, the type Rubiaceae 2 was frequent only in that month.

In addition to the plant species mentioned above, others also provided pollen to Scaptotrigona fulvicutis Moure 1964 in a lesser proportion and had attractiveness higher than $7,0 \%$ in certain months. These species were Tabebuia serratifolia (Vahl) G. Nicholson with $18,81 \%$ in August and 9,68\% in September. Mikania sp. that had its pollen harvested in July with an attractiveness of 8.18\%; Shizolobium amazonicum Huber ex Ducke with 8,39\% of attractiveness in October, Averrhoa carambola L. with $10,92 \%$ attractiveness in July and 7,15\% in December; Cupania hispida Radlk. with 10,19\% in August; the Myrtaceae taxon type with $10,45 \%$ in December.
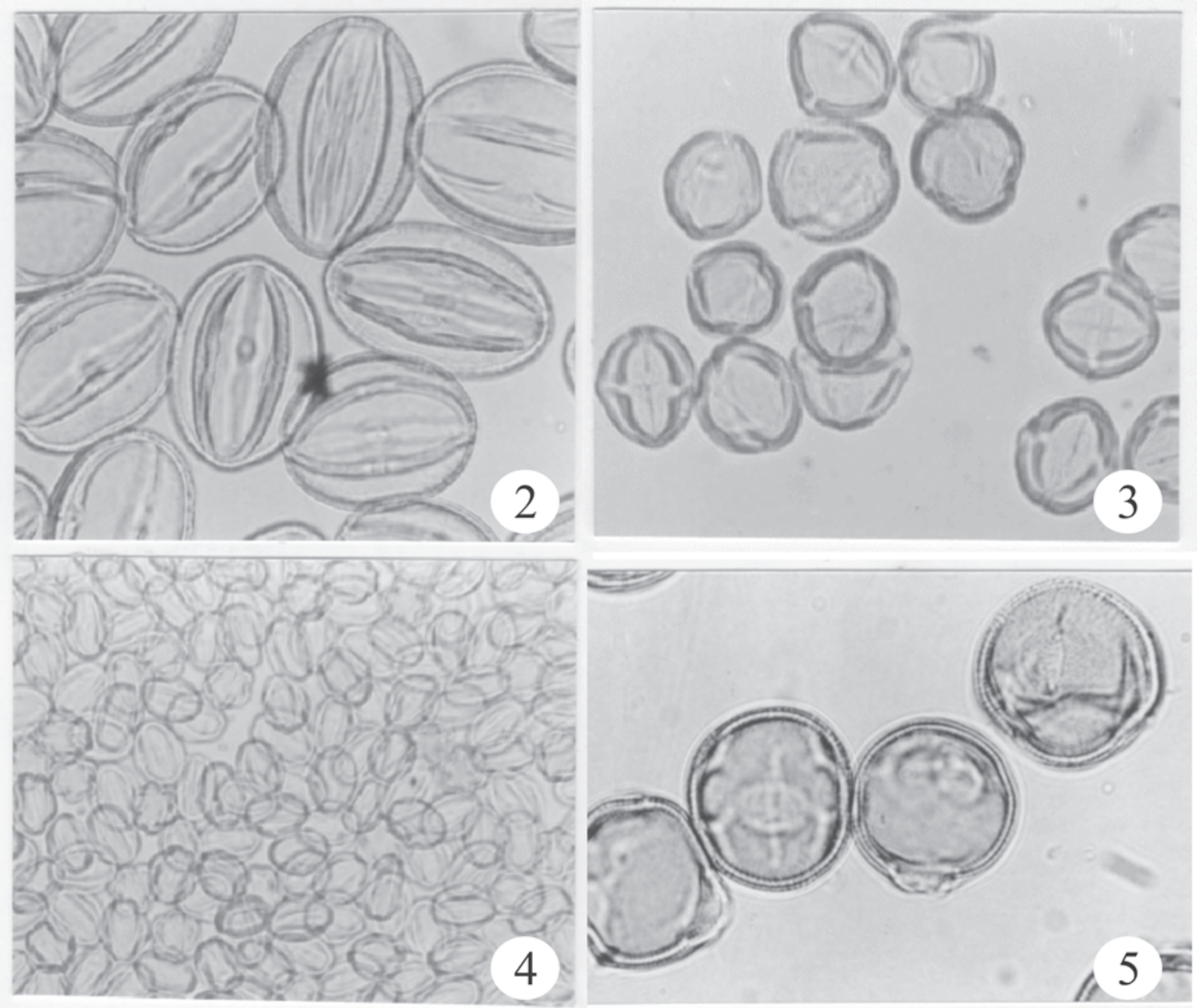

Figures 2-5. Grãos de pólen transportados por Scaptotrigona fulvicutis Moure 1964. 2. Cassia latifolia G. Mey. (40x). 3. Miconia myriantha Benth. (40x). 4. Tapirira guianensis Aubl. (40x). 5. Byrsonima sp. (100x). 
Matayba sp. 2 with 11,72\% in January; Sapindaceae taxon type with $29,73 \%$ in December and $10,26 \%$ in January; Carica papaya L. with $8,40 \%$ in October, Lantana camara L. with $7,58 \%$ in October; Byrsonima sp. with 7,44\% in December; Euphorbia sp. with $7,13 \%$ in November (Table 2).

\section{Discussion}

Grouping analyses are utilised as tools in order to determine the similarities amongst groups or individuals, in addition to being important indicators as to the species trophic niche evolution (Valentin 1995). Despite the low frequency of several plant species in the samples from Scaptotrigona fulvicutis Moure 1964, these data indicated a high degree of dispersion in the pollen harvests of this bee. They indicated the greatest pollen abundance in six plant species belonging to five families, which were present in the harvests of the two month groups. Even then, that little group dissimilarity indicates that plant communities harvested by workers are heterogeneous, since there were new pollen types incorporated to the diet of those bees every month, without them having to abandon their most attractive sources.

Ramalho (1990), when working with three types of Scaptotrigona Moure 1942, found that of the 92 plant species visited by those Meliponinae, 25 pollen types present in the samples represented less than $1 \%$. That is, $27 \%$ of the samples were of casual pollen (or isolated pollen). The author observed that pollen types with more than $1 \%$ in the samples belonged to small flowers with open corollas and short tubes.

Absy \& Kerr (1977), when analysing the pollen loads of Melipona seminigra merrillae Cockerell 1919, found that $61 \%$ of the pollen types in the samples belonged to a single plant species. Overall, the workers harvested the pollen from 25 genera belonging to 19 plant families over a period of one year. This is similar to observations by Marques-Souza (1996). Working in the same site for one year, he found that Melipona compressipes manaosensis Schwarz 1932 workers harvested the pollen from 30 plant species belonging to 22 genera and 19 families.

The presence of Scaptotrigona fulvicutis Moure 1964 in the flowers of Myrtaceae reinforces the observation that in any survey of the plants harvested by neotropical bees for pollen and/or nectar, species of Myrtaceae are always in evidence. CortopassiLaurino \& Ramalho (1988) found that in the percentages of pollen collected by Apis mellifera for two years, Myrtaceae was present in almost $50 \%$ of all collections and in over $30 \%$ in the ones harvested by Trigona spinipes.

Several other authors mention the importance of the family Myrtaceae in their studies. Absy et al. (1984) observed that fourteen bee species visited Myrtaceae flowers in order to collect pollen. Imperatriz-Fonseca et al. (1984), when analysing Tetragonisca angustula pollen and nectar collections, noted that of the 45 plant families present in the study, Myrtaceae was the one most sought for nectar and the fourth most visited for pollen. Ramalho et al. (1985), in their studies with Plebeia remota, observed that Myrtaceae were visited throughout the year, constituting one of that bee's most important sources of pollen and nectar. Kleinert-Giovannini \& Imperatriz-Fonseca (1987) observed that in the collections performed by Melipona marginata, Myrtaceae accounted for $88,5 \%$ of the harvested pollen, while $97,4 \%$ of the nectar. Guibu et al. (1988), reported Myrtaceae species as inexhaustible pollen and nectar sources for the bee Melipona quadrifasciata. Cortopassi-Laurino \& Ramalho (1988) observed that Myrtaceae species were the main sources of food for Trigona spinipes, from July to August and, for Apis mellifera from February to October. Marques-Souza et al. (1986), found that for several months Myrtaceae was the family that was most sought for pollen by five Amazonian bee species. With Myrcia amazônica DC. and Myrcia sp., being the main pollen sources for Melipona seminigra merrillae Cockerel 1919, Melipona rufiventris paraensis Ducke 1916, Melipona compressipes manaosensis Schwarz 1932, Trigona williana Friese 1900 and Frieseomelitta varia Lepeletier 1836.

According to the findings that were obtained it is possible to assert that the species Myrcia amazonica DC., Eugenia sp. and Syzygium jambolanum (Lam.) DC. possess year-round flowering. Yet, the other species in the family, Eugenia patrisii Vahl, Myrtaceae type, Psidium acutangulum DC. and Psidium sp. are seasonal plants with short flowering periods. The flowers of Myrcia amazonica DC. possess thick inflorescences with rimose anthers, which expose the pollen completely, facilitating harvest by Meliponinae. The seasonal plants are very important for the Amazonian native bees, since they provide an alternative food source during the decrease in the production of pollen and nectar in the rainy periods. At these times, it is difficult for the bees to find food (Gorenz 1967). 
Other families stood out during the study period because Scaptotrigona fulvicutis Moure 1964 harvested them in alternate days and even months. These are the families Melastomataceae and Mimosaceae, whose species were of significant value for that bee in August, April, June, and July.

Mimosaceae, Myrtaceae and Melastomataceae pollen is usually present in surveys of species that produce pollen and nectar. It is also present in any honey analyses, where reports of the productivity of the three families were frequent (Barth 1989; 1990; Iwama \& Melhem 1979; Carreira et al. 1986; Dutra \& Barth 1997).

The workers of Scaptotrigona fulvicutis Moure 1964 harvest different species of Mimosaceae. Mimosa pudica L. and Leucaena sp. had their pollen collected throughout the year. Inga sp. was another species harvested during the same months and, in June; Parkia sp. was the main source of pollen for Scaptotrigona fulvicutis Moure 1964.

Regarding the species of Mimosaceae, Sommeijer et al. (1983) reported three species of mimosas as being the ones most sought for in that family by Meliponinae, Trigonini, and Apis mellifera L. for the harvest of pollen and nectar. Ramalho et al. (1989) reported the Mimosaceae plants as important pollen and nectar sources for several species of Meliponinae. Other authors report the importance of the family Mimosaceae for the bees in their studies: Engel \& Dingemans-Bakels (1980), in samples of pollen and nectar harvested by several species of Meliponinae from Suriname; Absy et al. (1984) in samples of pollen stored by several Meliponinae from Amazonia; Kerr et al. (1986/1987) in pollen- and nectar supplying plants for Melipona compressipes fasciculata Smith 1854 in Maranhão; ImperatrizFonseca et al. (1989) in the pollen stored in eusocial bee communities; and Ramalho et al. (1994) in plants visited for nectar and pollen by Meliponinae and Apis in several habitats.

Of the other visited families, Anacardiaceae was very representative, having its species contribute significantly to the pollen collected in four months, from August to November. In September, pollen from species belonging to this plant family was the main source of protein for Scaptotrigona fulvicutis Moure 1964, with $45,94 \%$ of the collections.

The Anacardiaceae species harvest pattern shows that those plants are seasonal with short periods of flowering mostly restricted to the months of little rainfall.
Nectar is the floral reward offered by most Anacardiaceae species to the visitors. Species in this family possess flowers with rimose anthers and their pollen is totally exposed to the open air, thus visitors also harvest it opportunistically. Absy et al. (1980) found that Anacardiaceae species had their nectar collected by Melipona seminigra merrillae Cockerell 1919 over four months, and by Melipona rufiventris paraensis Ducke 1916 over nine months, the highest harvests occurring between August and October. Kerr et al. (1986/1987) observed that Melipona compressipes fasciculata Smith 1854 workers in Maranhão visited species of Anacardiaceae for nectar and pollen between August and November, with a plant few species extending their nectar secretion until January. According to those authors, another characteristic of some species from that family is the production of molasses. Marques-Souza et al. (1995) verified that the Anacardiaceae species were important sources of pollen and nectar for two Amazonian Meliponinae species, from August to November. Barth (1990) found pollen from Anacardiaceae species in honey samples from South Eastern Brazil.

In a community of plants where there are several kinds of bees, it is natural that all the bees will harvest all plants. Yet, it is also natural that within that community just one kind of bee will concentrate its foraging on just some plants. It is these feeding preferences of each bee, added to the monopolisation of the most attractive sources by a determined visitor, which makes species ecological niches different from one another (Absy et al. 1980).

Many plants visited by only one bee species, are often not the most attractive, they just represent food alternatives. Even when a bee species completely monopolises a feeding source - marking it with a pheromone, and visiting it with greater frequency - it will continue to seek other potential alternatives. It is common that Melipona Illiger 1806 species in the Amazonia possess one, two, and even three different pollen types in their corbiculae when captured (Absy $\&$ Kerr 1977). When quantified, one finds there is one clearly dominant species in these mixed collections (46-100\%), and that the other accessory species are present in much smaller amounts $(<16 \%)$.

In addition to this same pollen profile MarquesSouza et al. (1995), in a study carried out on Frieseomelitta varia Lepeletier 1836, on the other hand, found mixed collections where the secondary species were accessory, and concluded that, different Frieseomelitta varia Lepeletier 1836 workers spread 
out seeking separate pollen sources, whereas foraging Melipona Illiger 1806 all stick to the most productive resources.

Disperse foraging may be a communication problem between returning workers and the other bees in the hive, the former being unable to convey to the latter the exact location of pollen sources. Whatever the reason, the fact is that on a given day, Scaptotrigona fulvicutis Moure 1964 workers diversified their harvests and, consequently, harvested pollen from a larger number of plants over the entire study period. Santos (1991) observed that whenever they found flowers with a good food reward workers of Melipona seminigra merrillae Cockerell 1919 concentrated on those resources, taking the most advantage from them, and avoided plant species with less abundant pollen. Being the latter only exploited whenever there were no most advantageous sources.

In addition to the different foraging strategies, it is necessary to observe other factors affecting harvest choices of bees such as seasonal food shortage; morphology of the flower parts that may facilitate impede harvest, anthesis of the flowers; diurnal variation in the availability of pollen/nectar; the number of competitor insects; distance to the most attractive sources, communication between the bees pests and natural enemies, among others.

\section{Acknowledgements}

The authors thank to CNPq (SWE-Process 200038/96-6 and Process 471569/2001-1) for funding part of this study, Cleonice de Oliveira Moura for the pollen sample preparation, Dr. Edelcílio Marques Barbosa and Dra. Izildinha de Souza Miranda for their help and suggestions on the statistical part, Dr. Alexandre Coletto da Silva for his assistance, Jorge Antunes for his help in the English language composition, Dr. Bruce W. Nelson for revising the English composition and for his comments, questions and valuable suggestions.

\section{References}

Absy, M.L. \& Kerr, W.E. 1977. Algumas plantas visitadas para a obtenção de pólen por operárias de Melipona seminigra merrillae em Manaus. Acta Amazonica 7: 309-315.

Absy, M.L.; Bezerra, E.B. \& Kerr, W.E. 1980. Espécies nectaríferas utilizadas por duas espécies de Melipona da Amazônia. Acta Amazonica 10: 271-281.
Absy, M.L.; Camargo, J.M.F.; Kerr, W.E. \& Miranda, I.P.A. 1984. Espécies de plantas visitadas por Meliponinae (Hymenoptera; Apoidea), para coleta de pólen na região do médio Amazonas. Revista Brasileira de Biologia 44: 227-237.

Barth, M.O. 1989. O pólen no mel brasileiro. Rio de Janeiro, Gráfica Luxor.

Barth, M.O. 1990. Pollen in monofloral honeys from Brazil. Journal of Apicultural Research 29: 89-94.

Carreira, L.M.M.; Jardim, M.A.G.; Moura, C.O.; Pontes, M.A. \& Marques, R.V. 1986. Análise polínica dos méis de alguns municípios do Estado do Pará. Anais do $\mathbf{I}^{\mathbf{0}}$ Simpósio do Trópico Úmido, Belém (PA) 2: 79-84.

Cortopassi-Laurino, M. \& Ramalho, M. 1988. Pollen harvest by africanized Apis mellifera and Trigona spinipes in São Paulo botanical and ecological views. Apidologie 19: 1-24.

Cormack, R.M. 1971. A review of classification. Journal of the Royal Statistical Society, Series A, 134: 321-353.

Dutra, V.M.L. \& Barth, O.M. 1997. Análise palinológica de amostras de mel da região de Bananal (SP/RJ), Brasil. Revista da Universidade de Guarulhos, Geociências II: 174-183.

Engel, M.S. \& Dingemans-Bakels, F. 1980. Nectar and pollen resources for stingless bees (Meliponinae, Hymenoptera) in Surinam (South Amarica). Apidologie 11: 342-350.

Erdtman, G. 1960. The acetolisys method in a revised description. Svensk Botanisk Tidskrift Lund 54: 561-564.

Everitt, B. 1974. Cluster Analysis. Berlin, A Survey, SpringerVerlag.

Gorenz, A.M. 1967. Períodos de secreção nectarífera na região de Belém, Pará. Atas do Simpósio sobre a Biota Amazonica 5: 203-206.

Guibu, L.S.; Ramalho, M.; Kleinert-Giovannini, A. \& Imperatriz-Fonseca, V.L. 1988. Exploração dos recursos florais por colônias de Melipona quadrifasciata (Apidae, Meliponinae). Revista Brasileira de Biologia 48: 299-305.

Imperatriz-Fonseca, V.L.; Kleinert-Giovannini, A.; Cortopassi-Laurino, M. \& Ramalho, M. 1984. Hábitos de coleta de Tetragonisca angustula angustula Latreille, (Hymenoptera, Apidae, Meliponinae). Boletim de Zoologia da Universidade de São Paulo 8: 115-131.

Imperatriz-Fonseca, V.L.; Kleinert-Giovannini, A. \& Ramalho, M. 1989. Pollen harvest by eusocial bees in a non-natural community in Brazil. Journal of Tropical Ecology 5: 239-242.

Iwama, S. \& Melhem, T.S. 1979. The pollen spectrum of the honey of Tetragonisca angustula angustula Latreille (Apidae, Meliponinae). Apidologie 10: 275-295.

Johnson, L.K. \& Hubbell, S.P. 1974. Agression and competition among stingless bees: field studies. Ecology 55: 120-127.

Lobreau-Callen, D.; Le Thomas, A.; Darchen, B. \& Darchen, R. 1990. Quelques facteurs déterminant le comportement de butinage d'Hypotrigona pothieri (Trigonini) dans la végétation de Côte-d'Ivoire. Apidologie 21: 69-83. 
Kerr, W.E. 1978. Papel das abelhas sociais na Amazônia. Anais do Simpósio Internacional da Apimondia sobre Apicultura em clima quente. Florianópolis.

Kerr, W.E.; Absy, M.L. \& Marques-Souza, A.C. 1986/1987. Espécies nectaríferas e poliníferas utilizadas pela abelha Melipona compressipes fasciculata (Meliponinae, Apidae) no Maranhão. Acta Amazonica 16/17: 145-156.

Kleinert-Giovannini, A. \& Imperatriz-Fonseca, V.L. 1987. Aspects of the trophic niche of Melipona marginata marginata Lepeletier (Apidae, Meliponinae). Apidologie 18: $69-100$.

Marques-Souza, A.C.; Absy, M.L.; Kerr, W.E. \& Aguilera Peralta, F.J. 1995. Pólen coletado por duas espécies de meliponíneos (Hymenoptera: Apidae) da Amazônia. Revista Brasileira de Biologia 55: 855-864.

Marques-Souza, A.C. 1996. Fontes de pólen exploradas por Melipona compressipes manaosensis (Apidae: Meliponinae), abelha da Amazônia Central. Acta Amazonica 26: 77-86.

Marques-Souza, A.C.; Moura, C.O. \& Nelson, B.W. 1996. Pollen collected by Trigona williana (Hymenoptera: Apidae) in Central Amazonia. Revista de Biología Tropical 44: 567-573.
Nassar, N.M.A. \& Carvalho, C.G.P. 1990. Insetos polinizadores e seus comportamentos nas espécies silvestres da mandioca, Manihot spp. Ciência e Cultura 42: 703-706.

Ramalho, M.; Imperatriz-Fonseca, V.L.; Kleinert-Giovannini, A. \& Cortopassi-Laurino, M. 1985. Exploitation of floral resources by Plebeia remota Holmberg (Apidae, Meliponinae). Apidologie 16: 307-330.

Ramalho, M.; Kleinert-Giovannini, A. \& Imperatriz-Fonseca, V.L. 1989. Utilization of floral resources by species of Melipona (Apidae, Meliponinae): floral preferences. Apidologie 20: 185-195.

Ramalho, M. 1990. Foraging by stingless bees of thr genus, Scaptotrigona (Apidae, Meliponinae). Journal of Apicultural Research 29: 61-67.

Ramalho, M.; Giannini, T.C.; Malagodi-Braga, K.S. \& Imperatriz-Fonseca, V.L. 1994. Pollen harvest by stingless bee foragers (Hymenoptera, Apidae, Meliponinae). Grana 33: 239-244.

Sommeijer, M.J.; Rooy, G.A.; Punt, W. \& Bruijn, L.L.M. 1983. A comparative study of foraging behavior and pollen resources of various stingless bees (Hym., Meliponinae) and honeybees (Hym., Apinae) in Trinidad, West-Indies. Apidologie 14: 205-224.

Valentin, J.L. 1995. Agrupamento e ordenação. Oecologia Brasiliensis 2: 27-55. 